\title{
Preharvest UVB Application Increases Glucosinolate Contents and Enhances Postharvest Quality of Broccoli Microgreens
}

\author{
Yingjian Lu ${ }^{1,2}$, Wen Dong ${ }^{2}$, Tianbao Yang ${ }^{2, *}$, , Yaguang Luo ${ }^{2,3}$ and Pei Chen ${ }^{4}$ \\ 1 College of Food Science and Engineering, Nanjing University of Finance and Economics, \\ Nanjing 210095, China; yingiianlu@nufe.edu.cn \\ 2 Beltsville Agricultural Research Center, Food Quality Laboratory, U.S. Department of Agriculture, \\ Agricultural Research Service, Beltsville, MD 20705, USA; hanywenwen1986@gmail.com (W.D.); \\ Yaguang.Luo@ARS.USDA.GOV (Y.L.) \\ 3 Beltsville Agricultural Research Center, Environmental Microbial \& Food Safety Laboratory, U.S. Department \\ of Agriculture, Agricultural Research Service, Beltsville, MD 20705, USA \\ 4 Beltsville Human Nutrition Research Center, Methods and Application of Food Composition Laboratory, U.S \\ Department of Agriculture, Agricultural Research Service, Beltsville, MD 20705, USA; pei.chen@usda.gov \\ * Correspondence: tianbao.yang@usda.gov
}

check for updates

Citation: Lu, Y.; Dong, W.; Yang, T.; Luo, Y.; Chen, P. Preharvest UVB Application Increases Glucosinolate Contents and Enhances Postharvest Quality of Broccoli Microgreens. Molecules 2021, 26, 3247. https:// doi.org/10.3390/molecules26113247

Academic Editor: Carmen Cuadrado

Received: 6 May 2021

Accepted: 25 May 2021

Published: 28 May 2021

Publisher's Note: MDPI stays neutral with regard to jurisdictional claims in published maps and institutional affiliations.

Copyright: (c) 2021 by the authors. Licensee MDPI, Basel, Switzerland. This article is an open access article distributed under the terms and conditions of the Creative Commons Attribution (CC BY) license (https:// creativecommons.org/licenses/by/ $4.0 /)$.

\begin{abstract}
Broccoli microgreens have shown potential health benefits due to their high glucosinolate (GL) levels. Previously, we observed that postharvest UVB treatment did not have much effect on increasing GLs in broccoli microgreens. In this study, we investigated the influence of preharvest UVB irradiation on GL levels in broccoli microgreens. UHPLC-ESI/ITMS analysis showed that preharvest UVB treatments with UVB 0.09 and $0.27 \mathrm{Wh} / \mathrm{m}^{2}$ significantly increased the glucoraphanin (GLR), glucoerucin (GLE), and total aliphatic GL levels by 13.7 and 16.9\%, respectively, in broccoli microgreens when measured on harvest day. The nutritional qualities of UVB-treated microgreens were stable during 21-day storage, with only small changes in their GL levels. Broccoli microgreens treated before harvest with UVB $0.27 \mathrm{Wh} / \mathrm{m}^{2}$ and $10 \mathrm{mM} \mathrm{CaCl}_{2}$ spray maintained their overall quality, and had the lowest tissue electrolyte leakage and off-odor values during the storage. Furthermore, preharvest UVB $0.27 \mathrm{Wh} / \mathrm{m}^{2}$ treatment significantly increased GL biosynthesis genes when evaluated before harvest, and reduced the expression level of myrosinase, a gene responsible for GL breakdown during postharvest storage. Overall, preharvest UVB treatment, together with calcium chloride spray, can increase and maintain health-beneficial compound levels such as GLs and prolong the postharvest quality of broccoli microgreens.
\end{abstract}

Keywords: Brassica oleracea var. italica; phenolics; functional food; calcium; UVB radiation

\section{Introduction}

In recent years, consumption of microgreens has increased as a result of consumers' appreciation for their diverse flavors, beautiful colors, and highly nutritional value. Microgreens are seedlings of edible plants harvested around two weeks after germination at the emergence of the first true leaves [1]. Previous studies have shown that broccoli microgreens contain higher glucosinolate (GL) content than broccoli florets and mature leaves, indicating that microgreens are a richer source of GLs than mature broccoli [2]. Glucoraphanin (GLR) is the most abundant GL in broccoli heads, making up over $50 \%$ of the total GLs in broccoli heads, followed by glucoerucin (GLE) and glucoiberin [3,4]. GL hydrolysis products, especially sulforaphane (SFR) and erucin (ERC), have received much attention due to their chemopreventive capabilities [5]. Many studies have revealed that glucosinolates/isothiocyanates can potentially reduce the risk of chronic disease [6-8].

Environmental stresses can significantly influence the content of biologically active molecules in plants. Most notably, abiotic stresses, such as salinity, UVB, temperature, air pollution, heavy metal, and mechanical wounding, lead to changes in the secondary 
metabolism of plants [9]. For instance, flavonoids that are common in the plant kingdom are produced in response to almost all abiotic stresses [10]. In addition, UVB activates wound- and defense-signaling pathways that can cause an accumulation of secondary plant metabolites, such as flavonoids and other phenolic compounds [11]. GL levels in Brassica vegetables are determined mostly by genetic factors; however, abiotic stresses such as salinity and temperature can also influence the GL levels $[2,12,13]$. Postharvest exposure to a low UVB dose of up to $0.54 \mathrm{KJ} / \mathrm{m}^{2}$ induced a distinct increase in major GL derivatives in broccoli sprouts [2,14]. Heinze et al. [15] also reported that the exposure of Pal Choi (Brassica rapa subsp. chinensis) to reduced UVB dosages elevated the levels of GLs. Thus, the increase in GL levels in the secondary plant metabolism by UVB treatments have beneficial implications for humans. However, the effect of preharvest UVB radiation on shelf life and the levels of two major GLs, namely GLR and GLE, in broccoli microgreens has never been studied.

In Brassica vegetables, all of the GLs are synthesized from amino acids, for example, aliphatic glucosinolates from methionine, aromatic glucosinolates from phenylalanine, and indolic glucosinolates from tryptophan [16-21]. Two genes, methylthioalkylmalate synthase (MAM) and cytochrome (CYP79/CYP83), play important roles in the regulation of different stages of GLs synthesis. MAM catalyzes amino acid elongation, which serves as the substrate for GL synthesis. The CYP gene family plays an important role in synthesizing the core GLs from chain elongated methionine [21]. GLs are hydrolyzed by myrosinases (MY) to release glucose groups, and form isothiocyanates, thiocyanates, nitriles, etc. This breakdown is involved in defense signaling. Calcium treatment has been shown to increase both aliphatic and indolic GL levels, as well as the yield and shelf life of broccoli microgreens under both natural and stress conditions $[1,22,23]$. However, GL gene regulation in response to UVB treatment has not previously been studied.

In this study, we evaluated the effects of preharvest UVB treatment with and without $\mathrm{CaCl}_{2}$ spray on GL content and shelf life of broccoli microgreens, and the expression patterns of three key genes (MAM, CYP79F1, MY) involved in GL biosynthesis and catabolism.

\section{Materials and Methods}

\subsection{Seed Germination and Treatments}

The seeds of broccoli (Brassica oleracea var. italica) cultivar 'De Cicco' were obtained from a local seed store (Silver Spring, MD, USA) and grown in a plant growth chamber. The seed germination and further treatments followed previous protocol, as now described [1]. Seeds were sowed evenly on a hydroponic pad soaked with acidified water ( $\mathrm{pH}$ 5.6) and set in the dark for 4 days. On the fifth day, seedlings were exposed to light at an intensity of $42 \mu \mathrm{mol} \cdot \mathrm{s}^{-1} \cdot \mathrm{m}^{-2}$ light intensity for a $12 \mathrm{~h}$ photo period until harvest on day 10 after sowing. Broccoli seedlings were subjected to two different UVB levels: 0.09 and $0.27 \mathrm{~W}$ $\mathrm{h} / \mathrm{m}^{2}$ using a UVB fluorescent light source $(312 \mathrm{~nm})$ for an additional $2 \mathrm{~h}$ per day. The seedlings were sprayed once a day with water only (control) or $10 \mathrm{mM} \mathrm{CaCl}$. Microgreens were harvested by cutting the hypocotyl about $1 \mathrm{~cm}$ above the pad surface, and $10 \mathrm{~g}$ portions were sealed in $5 \mathrm{~cm} \times 5 \mathrm{~cm}$ sealed bags. Samples for postharvest evaluation were stored at $5{ }^{\circ} \mathrm{C}$. All others were frozen at $-80^{\circ} \mathrm{C}$.

\subsection{Extraction of Glucosinolates}

A modified procedure was used for GL extraction from microgreen samples [2]. First, frozen microgreen samples $(200 \mathrm{mg}$ ) were lyophilized for $48 \mathrm{~h}$ and milled into fine powders. Next, the powders were dissolved in $5 \mathrm{~mL}$ of $60 \%$ methanol-water and sonicated for $30 \mathrm{~min}$ at $70{ }^{\circ} \mathrm{C}$. The extracts were then cooled and centrifuged at $10,000 \times \mathrm{g}$ for $15 \mathrm{~min}$ at $4{ }^{\circ} \mathrm{C}$, and the final supernatant was filtered through a Waters $0.45 \mu \mathrm{m}$ nylon filter (Milford, MA, USA) for further ultra-high-performance liquid chromatography with electrospray ionization (UHPLC-ESI)/ion-trap mass spectrometry (ITMS) analysis. 


\subsection{UHPLC-ESI/ITMS}

An LC/MS system consisting of an Agilent 1200 UHPLC system with a diode array detector (DAD) (Agilent Technologies, Palo Alto, CA, USA) was used in combination with an LCQ Deca ion-trap mass spectrometer (Thermo Fisher Scientific Inc., Waltham, MA, USA). The temperature of the reverse phase C18 column $(2.1 \mathrm{~mm} \times 150 \mathrm{~mm}, 3.5 \mu \mathrm{m})$ (Waters, Milford, MA, USA) was set to $40{ }^{\circ} \mathrm{C}$.

We used a Milli-Q system (Millipore Lab., Bedford, MA, USA) to obtain HPLC-grade water. HPLC-grade methanol, formic acid, acetonitrile, and ethyl acetate were purchased from VWR International, LLC (Clarksburg, MD, USA). The glucoraphanin potassium salt and glucoerucin potassium salt were bought from Sigma-Aldrich Corporation (St. Louis. MO, USA). The UHPLC gradient method was set as follows: Mobile phase A: $0.1 \%$ formic acid in $\mathrm{H}_{2} \mathrm{O}$; Mobile phase B: $0.1 \%$ formic acid in acetonitrile. The starting percentage of mobile phase B was $2 \%$; this then changed linearly to $30 \%$ in $20 \mathrm{~min}$, elevated to $90 \%$ in $25 \mathrm{~min}$, and back to $2 \%$ in $26 \mathrm{~min}$. The gradient was then washed at $95 \% \mathrm{~B}$ for $5 \mathrm{~min}$ and returned to its initial condition ( $2 \% \mathrm{~B}$ ) for $5 \mathrm{~min}$ to re-equilibrate the column for the next injection. The injection volume was $20 \mu \mathrm{L}$ and the flow rate was $0.7 \mathrm{~mL} / \mathrm{min}$. The detecting wavelength was set to $229 \mathrm{~nm}$ [22].

The full scan mode of MS (100 and $700 \mathrm{~m} / \mathrm{z}$ ) was utilized to identify MS peak. ESI in negative ion was determined, and the ESI/ITMS parameters were followed below: sheath gas flow rate, 80 ; aux and sweep gases, 15 ; spray voltage, $3.5 \mathrm{kV}$; heated capillary temperature, $250{ }^{\circ} \mathrm{C}$; capillary voltage, $4.0 \mathrm{~V}$; tube lens offset, $20 \mathrm{~V}$. MS spectra were collected from 0 to $26 \mathrm{~min}$.

\subsection{Qualitative and Quantitative Analysis of GLs}

Glucoerucin and glucoraphanin were determined by their UV-visible chromatography, MS spectra, and the order of elution time from similar acquisition conditions as described [2]. The levels of glucoerucin and glucoraphanin were quantified by comparing with the integrating peak areas of a range of known concentrations of commercial standards. The Xcalibur 2.4 software (Thermo Fisher Scientific Inc., Waltham, MA, USA) was used to calculate the integrating peak areas.

\subsection{Postharvest Quality and Physiological Assessment}

The concentrations of carbon dioxide and oxygen in the headspace of sealed microgreen packages were measured using Checkmate II gas analyzer (PBI Dansensor Co., Denmark). Overall visual qualities were evaluated by ten highly trained people [24]. Offodor was scored on a 1-5 scale, where $1=$ no off-odor, and $5=$ extremely strong off-odor. Overall quality was evaluated with a 9-point hedonic scale, where $9=$ like extremely, $5=$ neither like nor dislike and $1=$ dislike extremely [25].

The tissue electrolyte leakage (TEL) was determined as described [1]. Briefly, threegram broccoli microgreens samples were immersed in distilled water for $30 \mathrm{~min}$ at $5{ }^{\circ} \mathrm{C}$. The electric conductivity of each sample was measured by the Orion Model 135A conductivity meter (Orion Research Inc., Franklin, MA, USA). Total sample conductivity was determined on the same solutions after freezing at $-20^{\circ} \mathrm{C}$ for $24 \mathrm{~h}$ and subsequent thawing. Tissue electrolyte leakage was expressed as a percentage of the total sample conductivity.

\subsection{Quantitative RT-PCR ( $q$ RT-PCR) Analysis}

The total RNA was isolated from broccoli microgreen samples using the RNeasy Plant Mini kit (Qiagen, Germantown, MD, USA). The total RNA was quantified by a NanoDrop 1000 spectrophotometer (Thermo Scientific, Waltham, MA, USA). One $\mu \mathrm{g}$ total RNA samples were used for reverse transcription using the iScript ${ }^{\mathrm{TM}}$ RT kit (BioRad, Hercules, CA, USA). The primer pairs, $5^{\prime}$-GGAGTTAGACGAAGTGGTGGGA-3' $/ 5^{\prime}$ TGTGGCTACCTTTGGGAATGA-3' , $^{\prime}$-AAGGTCGTCTGAAAGAGTTGGG-3' $/ 5^{\prime}$-TGATTT CGTTGTCGTTAGTGCC-3' ${ }^{\prime} 5^{\prime}$-GGTACATGGAGCCGCTAACA-3' $/ 5^{\prime}$-TTTGGCTGGGCGT ATTGAGT-3' ${ }^{\prime}$, and $5^{\prime}$-CCAGAGGTCTTGTCCAGCCATC- $3^{\prime} / 5^{\prime}$-GTTCCACCACTGAGCAC 
AATGTTAC-3' were used in the expression analysis of CYP79F1 (GenBank No. KP693683), MAM (GenBank No. AF399834.2), MY (GenBank No. EU004075) and BoACT (GenBank No. AF044573), respectively. RT-qPCR was performed with the following thermal cycle setting: $95^{\circ} \mathrm{C}$ for $2 \mathrm{~min}$, followed by 40 cycles of $95^{\circ} \mathrm{C}$ for $5 \mathrm{~s}$ and $60^{\circ} \mathrm{C}$ for $15 \mathrm{~s}$. The relative expression levels were calculated based on the $2^{-\Delta \Delta \mathrm{CT}}$ method [26], normalized by a housekeeping gene $A C T I N, B o A C T$, and expressed as fold changes (the lowest value $=1$ ).

\subsection{Statistical Analysis}

All the datasets are expressed as average \pm standard deviation $(n=3)$. Differences between means were determined by analysis of variance (ANOVA) with Tukey's HSD post hoc test $(p<0.05)$.

\section{Results and Discussion}

\subsection{Glucosinolate Levels of Microgreens during Cold Storage}

Our previous study showed that the preharvest $10 \mathrm{mM}$ calcium spray could significantly increase plant GL levels [2]. Thus, we applied one factor (calcium chloride: $10 \mathrm{mM}$ ) by two factor (UVB: 0.09 and $0.27 \mathrm{~W} \mathrm{~h} / \mathrm{m}^{2}$ ) treatments on the broccoli microgreens in this study. On harvest day (Day 0), broccoli microgreens treated with $10 \mathrm{mM} \mathrm{CaCl}_{2}$ and UVB $0.27 \mathrm{Wh} / \mathrm{m}^{2}$ showed the highest GLE, GLR, and total aliphatic GLS contents at $48.86,2.01$, and $50.87 \mu \mathrm{mol} / \mathrm{g} \mathrm{DW}$, respectively (Table 1). Compared to the negative control (without any treatment), treatments combining $10 \mathrm{mM} \mathrm{CaCl} 2$ and UVB elevated GLE and total aliphatic GLs by $61-69 \%$, followed by calcium only (35\% increase in GLs) and UVB only $(\sim 20 \%$ increase in GLs). These results indicate that preharvest calcium and UVB treatments stimulated GL accumulation in broccoli microgreens.

Table 1. Glucoraphanin, glucoerucin and total glucosinolate contents of preharvest UVB-treated broccoli microgreens during storage.

\begin{tabular}{|c|c|c|c|}
\hline & Glucoerucin $(\mu \mathrm{mol} / \mathrm{g})$ & $\begin{array}{l}\text { Glucoraphanin } \\
(\mu \mathrm{mol} / \mathrm{g})\end{array}$ & $\begin{array}{c}\text { Total } \\
(\mu \mathrm{mol} / \mathrm{g})\end{array}$ \\
\hline Day 0 Control & $28.89 \pm 0.57^{\mathrm{d}}$ & $1.51 \pm 0.03^{\mathrm{cd}}$ & $30.10 \pm 0.58^{d}$ \\
\hline Day $010 \mathrm{mM} \mathrm{CaCl}_{2}$ & $39.07 \pm 0.53^{f}$ & $1.68 \pm 0.02^{\mathrm{d}}$ & $40.75 \pm 0.54^{\mathrm{f}}$ \\
\hline Day 0 UV0.09 & $32.76 \pm 0.59^{\mathrm{e}}$ & $1.89 \pm 0.03^{\mathrm{e}}$ & $34.65 \pm 0.58^{\mathrm{e}}$ \\
\hline Day 0 UV0.27 & $33.76 \pm 0.37^{\mathrm{e}}$ & $1.93 \pm 0.06^{\mathrm{e}}$ & $35.69 \pm 0.32^{\mathrm{e}}$ \\
\hline Day $010 \mathrm{mM} \mathrm{CaCl}_{2}+\mathrm{UV} 0.09$ & $46.60 \pm 0.29 g$ & $2.00 \pm 0.04^{\mathrm{e}}$ & $48.59 \pm 0.31 \mathrm{~g}$ \\
\hline Day $010 \mathrm{mM} \mathrm{CaCl}_{2}+\mathrm{UV} 0.27$ & $48.86 \pm 2.24 \mathrm{~g}$ & $2.01 \pm 0.11^{\mathrm{e}}$ & $50.87 \pm 2.34 \mathrm{~g}$ \\
\hline Day 3 Control & $23.21 \pm 0.51^{\mathrm{c}}$ & $1.32 \pm 0.03^{c}$ & $24.53 \pm 0.53^{c}$ \\
\hline Day $310 \mathrm{mM} \mathrm{CaCl}_{2}$ & $36.08 \pm 1.34$ ef & $1.64 \pm 0.02^{d}$ & $37.72 \pm 1.36^{\text {ef }}$ \\
\hline Day 3 UV0.09 & $31.79 \pm 0.17^{\mathrm{e}}$ & $1.87 \pm 0.02 e^{\mathrm{e}}$ & $33.67 \pm 0.16^{\mathrm{e}}$ \\
\hline Day 3 UV0.27 & $32.80 \pm 0.98^{\mathrm{e}}$ & $1.92 \pm 0.02^{\mathrm{e}}$ & $34.72 \pm 1.00^{\mathrm{e}}$ \\
\hline Day $310 \mathrm{mM} \mathrm{CaCl}_{2}+\mathrm{UV} 0.09$ & $45.64 \pm 0.59 \mathrm{~g}$ & $1.97 \pm 0.05^{\mathrm{e}}$ & $47.60 \pm 0.56^{g}$ \\
\hline Day $310 \mathrm{mM} \mathrm{CaCl}_{2}+\mathrm{UV} 0.27$ & $47.15 \pm 1.88^{g}$ & $1.99 \pm 0.05^{\mathrm{e}}$ & $49.14 \pm 1.84^{g}$ \\
\hline Day 7 Control & $18.71 \pm 0.33^{b}$ & $1.01 \pm 0.02^{b}$ & $19.72 \pm 0.34^{b}$ \\
\hline Day $710 \mathrm{mM} \mathrm{CaCl}_{2}$ & $34.06 \pm 0.64 \mathrm{e}^{\mathrm{e}}$ & $1.54 \pm 0.01^{\mathrm{cd}}$ & $35.61 \pm 0.66^{\mathrm{e}}$ \\
\hline Day 7 UV0.09 & $29.42 \pm 1.82^{\mathrm{d}}$ & $1.78 \pm 0.06^{\mathrm{de}}$ & $31.20 \pm 1.77^{d}$ \\
\hline Day 7 UV0.27 & $30.17 \pm 0.18^{d}$ & $1.85 \pm 0.07^{\mathrm{e}}$ & $32.02 \pm 0.25^{\mathrm{d}}$ \\
\hline Day $710 \mathrm{mM} \mathrm{CaCl}_{2}+\mathrm{UV} 0.09$ & $45.01 \pm 0.83 \mathrm{~g}$ & $1.83 \pm 0.07 \mathrm{de}$ & $46.84 \pm 0.77 \mathrm{~g}$ \\
\hline Day $710 \mathrm{mM} \mathrm{CaCl}_{2}+\mathrm{UV} 0.27$ & $45.46 \pm 1.58 \mathrm{~g}$ & $1.86 \pm 0.03^{\mathrm{e}}$ & $47.32 \pm 1.56^{\mathrm{g}}$ \\
\hline Day 14 Control & $13.98 \pm 0.22^{\mathrm{a}}$ & $0.85 \pm 0.09^{a}$ & $14.83 \pm 0.30^{a}$ \\
\hline Day $1410 \mathrm{mM} \mathrm{CaCl}_{2}$ & $27.52 \pm 0.59^{d}$ & $1.37 \pm 0.07^{c}$ & $28.90 \pm 0.52^{d}$ \\
\hline Day 14 UV0.09 & $28.41 \pm 1.75^{\mathrm{d}}$ & $1.59 \pm 0.08^{\mathrm{cd}}$ & $30.00 \pm 1.77^{\mathrm{d}}$ \\
\hline Day 14 UV0.27 & $28.38 \pm 0.33^{d}$ & $1.64 \pm 0.05^{\mathrm{d}}$ & $30.11 \pm 0.38^{d}$ \\
\hline Day $1410 \mathrm{mM} \mathrm{CaCl}_{2}+\mathrm{UV} 0.09$ & $38.72 \pm 0.81^{\mathrm{f}}$ & $1.83 \pm 0.07$ de & $40.55 \pm 0.79^{\mathrm{f}}$ \\
\hline Day $1410 \mathrm{mM} \mathrm{CaCl}_{2}+\mathrm{UV} 0.27$ & $39.17 \pm 0.47^{\mathrm{f}}$ & $1.86 \pm 0.03^{\mathrm{e}}$ & $41.03 \pm 0.45^{\mathrm{f}}$ \\
\hline
\end{tabular}


Table 1. Cont.

\begin{tabular}{|c|c|c|c|}
\hline & Glucoerucin $(\mu \mathrm{mol} / \mathrm{g})$ & $\begin{array}{l}\text { Glucoraphanin } \\
(\mu \mathrm{mol} / \mathrm{g})\end{array}$ & $\begin{array}{c}\text { Total } \\
(\mu \mathrm{mol} / \mathrm{g})\end{array}$ \\
\hline Day 21 Control & $12.85 \pm 0.41^{\mathrm{a}}$ & $0.71 \pm 0.05^{\mathrm{a}}$ & $13.56 \pm 0.45^{\mathrm{a}}$ \\
\hline Day $2110 \mathrm{mM} \mathrm{CaCl}_{2}$ & $23.25 \pm 0.70^{c}$ & $1.14 \pm 0.07^{b}$ & $24.39 \pm 0.76^{\mathrm{c}}$ \\
\hline Day 21 UV0.09 & $21.62 \pm 0.38^{c}$ & $1.32 \pm 0.07^{\mathrm{c}}$ & $22.94 \pm 0.44^{\mathrm{c}}$ \\
\hline Day 21 UV0.27 & $22.62 \pm 1.22^{\mathrm{c}}$ & $1.43 \pm 0.05^{\mathrm{c}}$ & $24.05 \pm 1.24^{\mathrm{c}}$ \\
\hline Day $2110 \mathrm{mM} \mathrm{CaCl}_{2}+\mathrm{UV} 0.09$ & $34.44 \pm 0.47^{\mathrm{e}}$ & $1.41 \pm 0.06^{\mathrm{c}}$ & $35.85 \pm 0.53^{\mathrm{e}}$ \\
\hline Day $2110 \mathrm{mM} \mathrm{CaCl}_{2}+\mathrm{UV} 0.27$ & $36.15 \pm 0.47$ ef & $1.44 \pm 0.03^{\mathrm{c}}$ & $37.59 \pm 0.43^{\text {ef }}$ \\
\hline
\end{tabular}

All the data are expressed as Mean $\pm \mathrm{SD}$ of three replicates followed by a letter. The same letter means no statistical difference whereas different letters indicate a significant statistical difference $(p>0.05)$.

Furthermore, the control GLE and GLR levels decreased up to 56\% from Day 0 to 21 during storage. However, all UVB-treated microgreens showed slower reduction rates (less than $30 \%$ ) of GLs than other treatments. In the first week of storage, GLs after UV treatment decreased by less than $5 \%$ of the GL levels. Specifically, GLE in $\mathrm{CaCl}_{2}$ plus UV 0.09 $\mathrm{Wh} / \mathrm{m}^{2}$ and $\mathrm{CaCl}_{2}$ plus UV $0.27 \mathrm{Wh} / \mathrm{m}^{2}$-treated microgreens decreased from 46.60 and $48.86 \mu \mathrm{mol} / \mathrm{g}$ on Day 0 to 45.64 and $47.15 \mu \mathrm{mol} / \mathrm{g}$ on Day 3, and 45.01 and $45.46 \mu \mathrm{mol} / \mathrm{g}$ on Day 7, respectively. A similar trend was found for GLR in UVB-treated samples during the 7-day storage. On Day 21, $10 \mathrm{mM} \mathrm{CaCl}_{2}+\mathrm{UV0} .09$ and $10 \mathrm{mM} \mathrm{CaCl}_{2}+\mathrm{UV} 0.27$-treated microgreens contained 34.44 and $36.15 \mu \mathrm{mol} / \mathrm{g}$ of GLE, respectively, on Day 21, which was only reduced by $26.1 \%$ and $26.0 \%$ from levels observed on Day 0 . Overall, the nutritional quality of all UVB-treated microgreens was relatively stable during the entire storage period ( 21 days) and especially during the second-week storage, with only minor changes in terms of GL content.

\subsection{Effects of UVB Treatments on Microgreen Postharvest Quality Traits}

The $\mathrm{CO}_{2}$ partial pressures in all treatments dramatically increased from Day 0 through 3, decreased gradually from Day 3 to Day 7, and then maintained a steady level from Day 7 to the end of storage. There were no significant differences in $\mathrm{CO}_{2}$ partial pressures among different treatments and control (Figure 1A).

The oxygen-partial pressures in water-control packages decreased rapidly from $21.0 \mathrm{kPa}$ to $1.3 \mathrm{kPa}$ on Day 3 and continued to decline steadily to 0.4 on Day 21 (Figure 1B). Samples treated with $10 \mathrm{mM} \mathrm{CaCl} 2$ plus UV showed significantly higher oxygen-partial pressures $(2.0-2.2 \mathrm{kPa})$ than controls on Day 3. However, there were no statistical differences in oxygen-partial pressures among treatments at other time points during storage.

We further examined the off-odor and overall visual quality for each treatment. Wateronly treated seedlings yielded highest off-odor scores throughout storage (Figure 2A), and worst overall quality (Figure 2B). All calcium and UVB-treated samples had less off-odor than water-treated samples. Among them, the samples treated with $10 \mathrm{mM} \mathrm{CaCl} 2$ plus UVB $0.27 \mathrm{Wh} / \mathrm{m}^{2}$ had the least off-odor from Day 7 to Day 21, and best overall visual quality from Day 3 to Day 21. The results indicate that the microgreens treated with UVB $0.27 \mathrm{Wh} / \mathrm{m}^{2}$ after calcium spray retained the best postharvest quality and the longest shelf life, and were the only samples still acceptable (having an overall quality score of at least 7.0) on Day 14 of storage.

We further measured TEL (total electrolyte leakage), which is closely related to tissue damage and fresh produce shelf life [23]. TEL in the water-only control increased sharply from Day 7 to Day 21, namely from 3.2 to $15.1 \%$ (Figure 3). In contrast, all preharvest UVB and calcium spray-treated microgreens significantly reduced the electrolyte leakage during the 21-day storage, and TEL increased only slightly from 3.0 to $3.6 \%$. In general, the $10 \mathrm{mM} \mathrm{CaCl}$ with UVB $0.27 \mathrm{Wh} / \mathrm{m}^{2}$ treatment was the most effective for maintaining fresh appearance and overall quality throughout the storage period. Additionally, the lowest TEL values and off-odor scores were observed for these samples during the 21-day storage. 


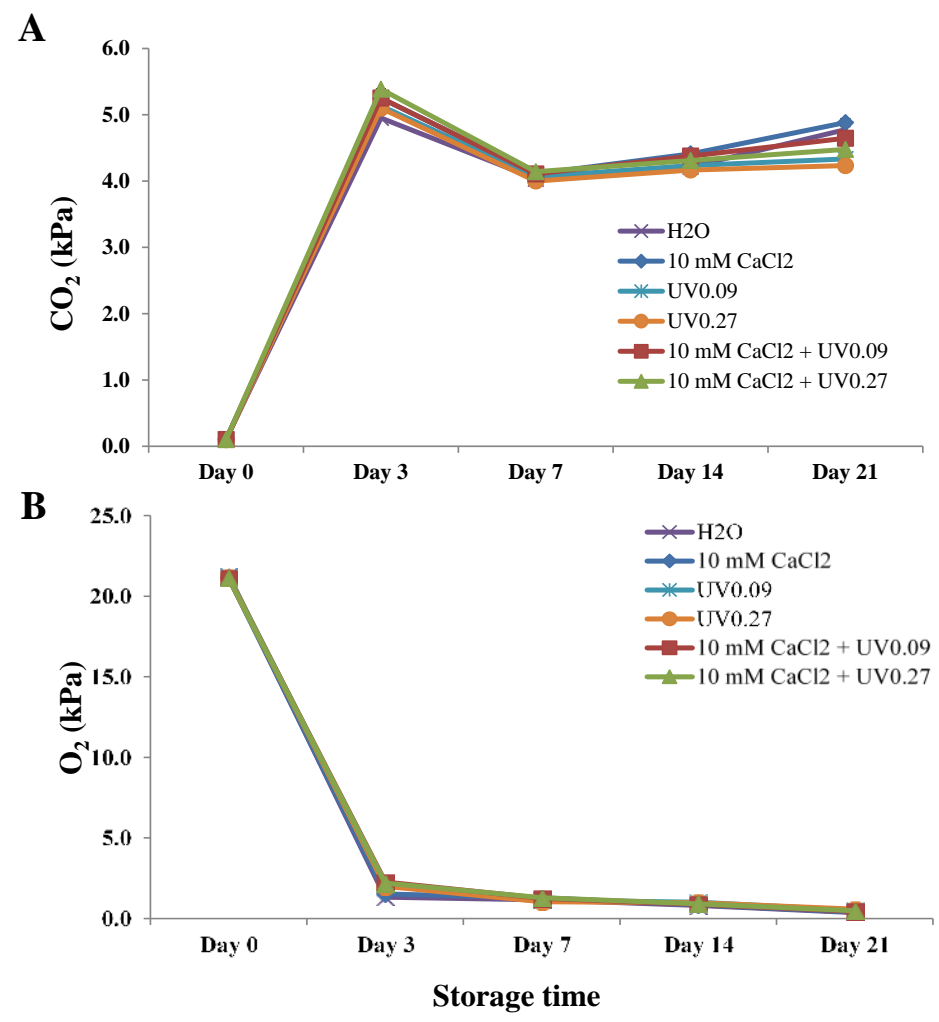

Figure 1. Effects of preharvest treatments on $\mathrm{CO}_{2-}(\mathbf{A})$ and $\mathrm{O}_{2-}(\mathbf{B})$ partial pressure within package on broccoli microgreens during cold storage $\left(4^{\circ} \mathrm{C}\right)$. UV0.09: $0.09 \mathrm{Wh} / \mathrm{m}^{2} \mathrm{UVB}$; UV0.27: $0.27 \mathrm{Wh} / \mathrm{m}^{2}$ UVB. Data presented are the means of three replicates.

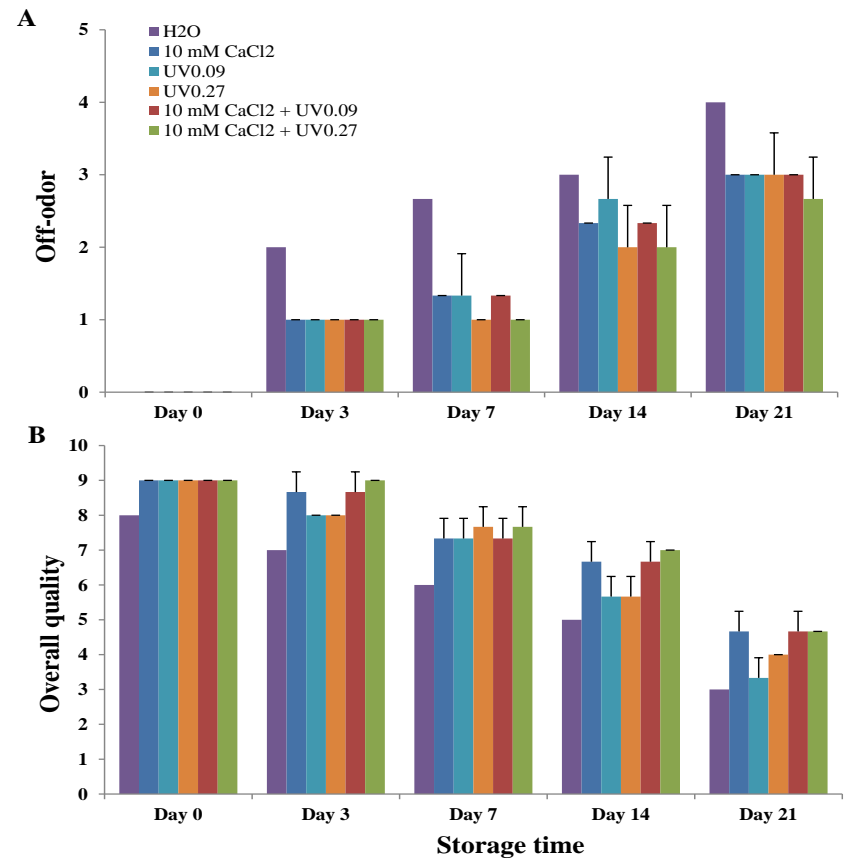

Figure 2. Effects of preharvest treatments on off-odor (A) and overall quality (B) of broccoli microgreens during cold storage $\left(4^{\circ} \mathrm{C}\right)$. UV0.09: $0.09 \mathrm{Wh} / \mathrm{m}^{2} \mathrm{UVB}$; UV0.27: $0.27 \mathrm{Wh} / \mathrm{m}^{2} \mathrm{UVB}$. Data presented are the means of three replicates; vertical lines represent standard deviation. 


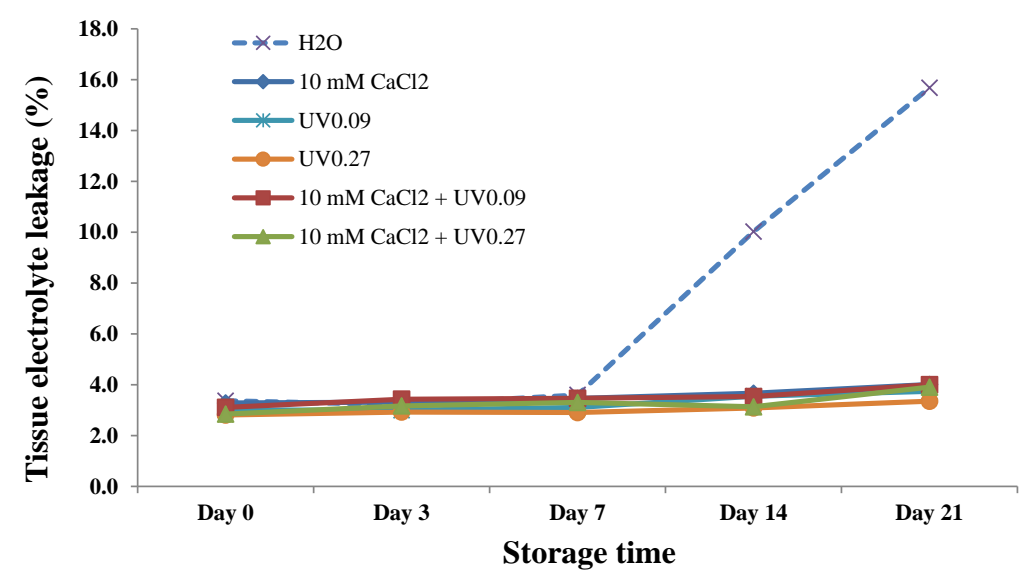

Figure 3. Effect of preharvest treatments on tissue electrolyte leakage of broccoli microgreens after 0, 3, 7, 14, and $21 \mathrm{~d}$ of storage at $4{ }^{\circ} \mathrm{C}$. UV0.09: $0.09 \mathrm{Wh} / \mathrm{m}^{2} \mathrm{UVB}$; UV0.27: 0.27Wh/ $\mathrm{m}^{2} \mathrm{UVB}$. Data presented are the means of three replicates.

\subsection{Expression Changes of Glucosinolate Biosynthetic and Breakdown Genes during Storage}

We investigated the changes in expression of two key genes, MAM and CYP79F1, in the glucosinolate biosynthetic pathway from Day 0 to Day 21. On Day 0, the expression levels of MAM and CYP79F1 in microgreens treated with UVB $0.27 \mathrm{Wh} / \mathrm{m}^{2}$ with $10 \mathrm{mM}$ $\mathrm{CaCl}_{2}$ spray were significantly higher than others. For example, CYP79F1 and MAM expression levels were higher by 12 and 10 fold, respectively, than for the water-only control (Figure 4A,B). During cold storage, the expression of MAM and CYP79F1 was reduced significantly in all treatments. However, the expression levels of $M A M$ and CYP79F1 in UVB-treated samples were still higher than in controls (water-only treatment). These results suggest that preharvest UVB and calcium treatments boost the expression of genes for GL biosynthesis, but do not have much impact on the expression of those genes during postharvest storage.

We also evaluated the expression of $M Y$ involved in GL breakdown during storage. On Day 0, there were no significant differences among controls (water only) and all other treatments in expression level of $M Y$ (Figure 4C). After cold storage, the expression levels of $M Y$ in controls on Day 7 and 14 were increased by about 24- and 28-fold, respectively, as compared to the expression levels observed on harvest day, indicating that GL degradation occurred dramatically during storage in these samples. However, $M Y$ levels in the samples treated with $10 \mathrm{mM}$ calcium alone, UVB $0.27 \mathrm{Wh} / \mathrm{m}^{2}$ alone, and calcium plus UVB were much lower than those in controls, even though $M Y$ expression in all treatments was higher on Day 7 and 14 than on Day 0. For example, on Day 7 and 14, MY levels in UVB treated samples were 3.1- and 2.2-fold less, respectively, than in controls. No significant differences were observed between calcium and UVB treatments. Nonetheless, the samples treated with the combination of UVB and calcium displayed significantly lower $M Y$ levels on Day 7 and 14. Hence, MY expression levels correlated to the GL levels during storage (Table 1 and Figure 4). These results suggest that the reduction in GLs in broccoli microgreens during postharvest storage mainly resulted from $M Y$ catalyzed GL breakdown. UVB and calcium treatments might delay GL breakdown by reducing $M Y$ expression during postharvest storage. 


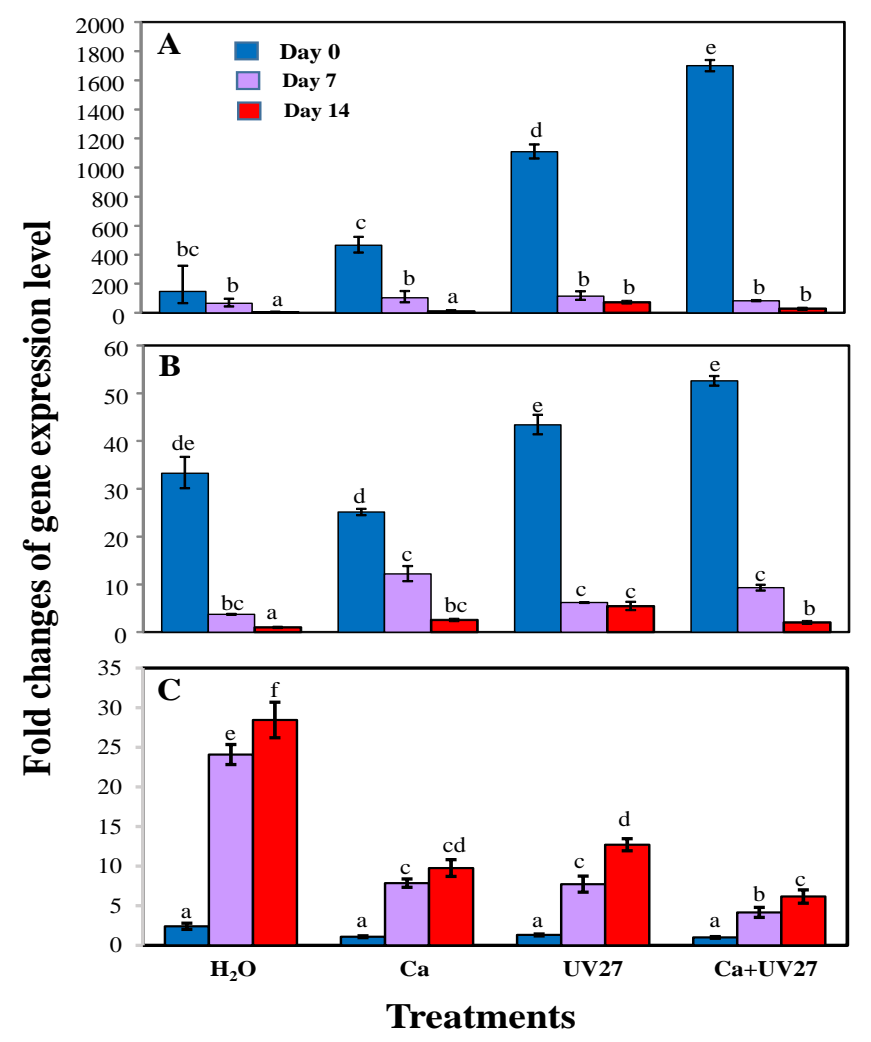

Figure 4. Expression patterns of glucosinolate structural genes CYP79F1 (A), MAM (B) and MY (C) during postharvest storage. Ca: $10 \mathrm{mM} \mathrm{CaCl}_{2} ; \mathrm{UV} 27: 0.27 \mathrm{Wh} / \mathrm{m}^{2} \mathrm{UVB}$. Total RNA was extracted from microgreens on Day 0 (harvest day), Day 7, and Day 14. ACTIN was used as the internal control. Error bars represent standard error of the mean. Different letters indicate significant differences among mean values $(p<0.05 ;$-test). Data presented are the means of three replicates.

\section{Conclusions}

GLs are unique antioxidants produced in Brassica vegetables such as broccoli and show great health benefits for human health. These compounds are also regarded as signal molecules for plants to respond to oxidative stress caused by biotic and abiotic stresses. Our study indicates that preharvest UVB treatments plus $10 \mathrm{mM} \mathrm{CaCl}$ spray significantly elevated the concentrations of GLE, GLR, and total aliphatic GLs by around 70\% in broccoli microgreens as compared to untreated controls. The nutritional qualities of the two groups of UVB-treated microgreens were stable during 21-day storage, with only small changes in their GL contents. The UVB $0.27 \mathrm{Wh} / \mathrm{m}^{2}$ with $10 \mathrm{mM} \mathrm{CaCl}_{2}$ spray-treated broccoli microgreens maintained their overall quality throughout shelf life, and showed the lowest TEL and off-odor values during the 14- and 21-day evaluations. Glucosinolate levels were found to have a significant positive correlation with overall quality, and negative correlation with off-odor in broccoli microgreens. Furthermore, UVB $0.27 \mathrm{Wh} / \mathrm{m}^{2}$ and/or calcium treatment of microgreens significantly reduced the expression of $M Y$, a key gene responsible for GL breakdown during postharvest storage, suggesting that $M Y$ level could be used as a molecular marker to predict broccoli microgreen postharvest quality and shelf life. This study also provides an efficient and simple method to enhance the health-beneficial compounds in broccoli microgreens, which can be utilized by industry. 
Author Contributions: Y.L. (Yingjian Lu) and W.D. performed the experiments, analyzed the data, and wrote the first draft of the manuscript. T.Y., Y.L. (Yaguang Luo) and P.C. were involved in data analysis and editing of the manuscript. T.Y. designed and coordinated the whole project. All authors have read and agreed to the published version of the manuscript.

Funding: This research is supported and funded by the U.S. Department of Agriculture-Agricultural Research Service (USDA-ARS): Grants No. 8042-43440-005-00D and 8042-43000-015-00D.

Institutional Review Board Statement: Not applicable.

Informed Consent Statement: Not applicable.

Data Availability Statement: The authors declare that all data generated or analyzed during this study are included in this published article.

Acknowledgments: We thank Frances Trouth for technical assistance, Xudong Zhu and Ellen Turner for critical reading of the manuscript.

Conflicts of Interest: The authors declare no conflict of interest.

Sample Availability: Not applicable.

\section{References}

1. Kou, L.; Yang, T.; Luo, Y.; Liu, X.; Huang, L.; Codling, E. Pre-harvest calcium application increases biomass and delays senescence of broccoli microgreens. Postharvest Biol. Technol. 2014, 87, 70-78. [CrossRef]

2. Lu, Y.; Dong, W.; Alcazar, J.; Yang, T.; Luo, Y.; Wang, Q.; Chen, P. Effect of preharvest $\mathrm{CaCl}_{2}$ spray and postharvest UV-B radiation on storage quality of broccoli microgreens, a richer source of glucosinolates. J. Food Compos. Anal. 2018, 67, 55-62. [CrossRef]

3. Guo, R.F.; Yuan, G.F.; Wang, Q.M. Effect of sucrose and mannitol on the accumulation of health-promoting compounds and the activity of metabolic enzymes in broccoli sprouts. Sci. Hortic. 2011, 128, 159-165. [CrossRef]

4. Martinez-Villaluenga, C.; Peñas, E.; Ciska, E.; Piskula, M.K.; Kozlowska, H.; Vidal-Valverde, C.; Frias, J. Time dependence of bioactive compounds and antioxidant capacity during germination of different cultivars of broccoli and radish seeds. Food Chem. 2010, 120, 710-716. [CrossRef]

5. Weng, R.; Tsai, C.H.; Kulp, S.K.; Chen, C.S. Indole-3-carbinol as a chemopreventive and anti-cancer agent. Cancer Lett. 2008, 262, 153-163. [CrossRef]

6. Barillari, J.; Canistro, D.; Paolini, M.; Ferroni, F.; Pedulli, G.F.; Iori, R.; Valgimigli, L. Direct antioxidant activity of purified glucoerucin, the dietary secondary metabolite contained in rocket (Eruca sativa Mill.) seeds and sprouts. J. Agric. Food Chem. 2005, 53, 2475-2482. [CrossRef] [PubMed]

7. Fahey, J.W.; Talalay, P. Antioxidant functions of sulforaphane: A potent inducer of Phase II detoxication enzymes. Food Chem. Toxicol. 1999, 37, 973-979. [CrossRef]

8. Nestle, M. Broccoli sprouts as inducers of carcinogen-detoxifying enzyme systems: Clinical, dietary, and policy implications. Proc. Natl. Acad. Sci. USA 1997, 94, 11149-11151. [CrossRef]

9. Suzuki, N.; Rivero, R.M.; Shulaev, V.; Blumwald, E.; Mittler, R. Abiotic and biotic stress combinations. New Phytol. 2014, 203, 32-43. [CrossRef] [PubMed]

10. Tohge, T.; Watanabe, M.; Hoefgen, R.; Fernie, A.R. The evolution of phenylpropanoid metabolism in the green lineage. Crit. Rev. Biochem. Mol. Biol. 2012, 48, 123-152. [CrossRef] [PubMed]

11. Kuhlmann, F.; Muller, C. Independent responses to ultraviolet radiation and herbivore attack in broccoli. J. Exp. Bot. 2009, 60, 3467-3475. [CrossRef] [PubMed]

12. Jones, R.B.; Faragher, J.D.; Winkler, S. A review of the influence of postharvest treatments on quality and glucosinolate content in broccoli (Brassica oleracea var. Italica) heads. Postharvest Biol. Technol. 2006, 41, 1-8. [CrossRef]

13. Verkerk, R.; Schreiner, M.; Krumbein, A.; Ciska, E.; Holst, B.; Rowland, I.; De Schrijver, R.; Hansen, M.; Gerhäuser, C.; Mithen, R.; et al. Glucosinolates in Brassica vegetables: The influence of the food supply chain on intake, bioavailability and human health. Mol. Nutr. Food Res. 2008, 53, S219-S265. [CrossRef] [PubMed]

14. Mewis, I.; Schreiner, M.; Nguyen, C.N.; Krumbein, A.; Ulrichs, C.; Lohse, M.; Zrenner, R. UV-B irradiation changes specifically the secondary metabolite profile in broccoli sprouts: Induced signaling overlaps with defense response to biotic stressors. Plant Cell Physiol. 2012, 53, 1546-1560. [CrossRef]

15. Heinze, M.; Hanschen, F.S.; Wiesner-Reinhold, M.W.; Baldermann, S.; Gräfe, J.; Schreiner, M.; Neuqart, S. Effects of developmental stages and reduced UVB and low UV conditions on plant secondary metabolite profiles in Pak Choi (Brassica rapa subsp. chinensis). J. Agric. Food Chem. 2018, 66, 1678-1692. [CrossRef] [PubMed]

16. Guo, L.; Yang, R.; Gu, Z. Cloning of genes related to aliphatic glucosinolate metabolism and the mechanism of sulforaphane accumulationin broccoli sprouts under jasmonic acid treatment. J. Sci. Food Agric. 2016, 96, 4329-4336. [CrossRef]

17. Grubb, C.D.; Abel, S. Glucosinolate metabolism and its control. Trends Plant Sci. 2006, 11, 89-100. [CrossRef] 
18. Sønderby, I.E.; Hansen, B.G.; Bjarnholt, N.; Ticconi, C.; Halkier, B.A.; Kliebenstein, D.J. A systems biology approach identifies a R2R3 MYB gene subfamily with distinct and overlapping functions in regulation of aliphatic glucosinolates. PLoS ONE 2007, 2, 1322. [CrossRef]

19. Levy, M.; Wang, Q.; Kaspi, R.; Parrella, M.; Abel, S. Arabidopsis IQD1, a novel calmodulin-binding nuclear protein, stimulates glucosinolate accumulation and plant defense. Plant J. 2005, 43, 79-96. [CrossRef] [PubMed]

20. Zang, Y.X.; Kim, H.U.; Kim, J.A.; Lim, M.H.; Jin, M.; Lee, S.C.; Kwon, S.-J.; Lee, S.-I.; Hong, J.K.; Park, T.-H.; et al. Genome-wide identification of glucosinolate synthesis genes in Brassica rapa. FEBS J. 2009, 276, 3559-3574. [CrossRef]

21. Hansen, C.H.; Wittstock, U.; Olsen, C.E. Cytochrome P450 CYP79F1 from Arabidopsis catalyzes the conversion of dihomomethionine and trihomomethionine to the corresponding aldoximes in the biosynthesis of aliphatic glucosinolates. J. Biol. Chem. 2001, 276, 11078-11085. [CrossRef] [PubMed]

22. Sun, J.; Kou, L.; Geng, P.; Huang, H.; Yang, T.; Luo, Y.; Chen, P. Metabolomic assessment reveals an elevated level of glucosinolate content in $\mathrm{CaCl}_{2}$ treated broccoli microgreens. J. Agric. Food Chem. 2015, 63, 1863-1868. [CrossRef]

23. Singh, D.P.; Beloy, J.; McInerney, J.K.; Day, L. Impact of boron, calcium and genetic factors on vitamin C, carotenoids, phenolic acids, anthocyanins and antioxidant capacity of carrots (Daucus carota). Food Chem. 2012, 132, 1161-1170. [CrossRef] [PubMed]

24. Luo, Y.; McEvoy, J.; Wachtel, M. Package atmosphere affects postharvest biology and quality of fresh-cut cilantro leaves. HortScience 2004, 39, 567-570. [CrossRef]

25. Meilgaard, M.C. Individual differences in sensory threshold for aroma chemicals added to beer. Food Qual. Prefer. 1993, 4, $153-167$. [CrossRef]

26. Schmittgen, T.D.; Livak, K.J. Analyzing real-time PCR data by the comparative C(T) method. Nat. Protoc. 2008, 3, 1101-1108. [CrossRef] [PubMed] 